\title{
Pengasuh berhubungan dengan keberhasilan pemberian ASI eksklusif pada baduta di Kecamatan Sedayu
}

\author{
Care taker was associated with the success in providing exclusive breastfeeding of baduta in \\ Sedayu District
}

Siti Nurunniyah ${ }^{1}$, Dian Tri Sugesti ${ }^{1}$

\begin{abstract}
Background: The success of exclusive breastfeeding is influenced by several factors. One of them is the care taker contacts of children and old nursing mothers with children. Many mothers who leave their children because of work. It makes contact duration of mothers with their children becomes limited.

Objectives: This research aimed to determine the relationship between parenting with the success of exclusive breastfeeding in District of Sedayu, Bantul, Yogyakarta.

Methods: This research was quantitative analytical approach and reinforced with qualitative approach. This study used cross sectional design. The population in this study were all mothers with the children under two years old in the District of Sedayu, Bantul, Yogyakarta. The samples used in this study were 292 respondents that were selected by using techniques of probability proportional to size (PPS). Data were then collected using questionnaires and analyzed by using chi -square.

Results: There was significant relationship between parenting with the success of exclusive breastfeeding $(p=0,019)$.

Conclusions: There was relationship between parenting with the success of exclusive breastfeeding
\end{abstract}

KEYWORDS:parenting, care taker, exclusive breastfeeding

\begin{abstract}
ABSTRAK
Latar belakang: Keberhasilan pemberian ASI eksklusif dipengaruhi oleh beberapa faktor, salah satunya adalah pengasuh utama anak dan lama kontak ibu menyusui dengan anak. Banyak ibu yang menitipkan anaknya karena bekerja, sehingga lama kontak ibu menyusui dengan anak menjadi terbatas.

Tujuan: Penelitian ini bertujuan untuk mengetahui hubungan antara pola asuh dengan keberhasilan pemberian ASI eksklusif di Kecamatan Sedayu, Kabupaten Bantul, Yogyakarta.

Metode: Penelitian ini merupakan penelitian analitik dengan pendekatan kuantitatif dan diperkuat dengan pendekatan kualitatif. Penelitian ini menggunakan rancangan penelitian cross sectional. Populasi dalam penelitian ini adalah seluruh ibu yang memiliki anak di bawah umur dua tahun (baduta) di Kecamatan Sedayu.Sampel yang digunakan dalam penelitian ini sebanyak 292 responden menggunakan teknik probability propotional to size (PPS). Data dikumpulkan menggunakan kuesioner dan kemudian dianalisis menggunakan uji statistik chi-square.
\end{abstract}

Hasil: Ada hubungan yang signifikan antara pengasuh dengan pemberian ASI secara eksklusif $(p=0,019)$.

Kesimpulan: Ada hubungan antara pengasuh dengan pemberian ASI secara eksklusif.

KATA KUNCI:pola asuh, pengasuh, ASI eksklusif

\footnotetext{
${ }_{1}$ Program Studi D3 IImu Kesehatan, Fakultas IImu Kesehatan Universitas Alma Ata, Jl. Ring Road Barat Daya No 1, Taman Tirto, Kasihan, Bantul, Yogyakarta, email: nurunniyah.siti@almaata.ac.id
} 


\section{PENDAHULUAN}

Survei Demografi Kesehatan Indonesia (SDKI) tahun 2012 mengumpulkan data tentang pemberian makanan pada bayi untuk semua anak terakhir yang dilahirkan dalam kurun waktu dua tahun sebelum survei (1). Dari data yang didapat menunjukkan bahwa hanya $27 \%$ bayi umur $4-5$ bulan yang mendapat ASI eskklusif (tanpa tambahan makanan atau minuman lain). Selain $\mathrm{ASI}, 8 \%$ bayi pada umur yang sama diberi susu lain dan $12 \%$ air putih. Pemberian ASI eksklusif kepada bayi berusia 4-5 bulan dalam SDKI 2012 lebih tinggi dibandingkan dengan hasil SDKI 2007 ( masingmasing $27 \%$ dan $17 \%$ ) (1).

ASImengandung semuazat giziyang diperlukan bayi dalam enam bulan pertama. Pemberian ASI secara eksklusif terbukti meningkatkan kekebalan tubuh bayi, menghindari alergi, meningkatkan kedekatan ibu dan bayi, serta hemat. Pemberian pengganti air susu ibu (PASI) sebelum anak berumur enam bulan tidak dianjurkan, karena dapat meningkatkan kemungkinan terkontaminasi dan meningkatkan risiko terkena penyakit, khususnya diare. Setelah anak berusia enam bulan sesuai dengan proses pertumbuhan dan perkembangan bayi, maka ASI harus ditambah dengan cairan lain dan makanan padat untuk memberikan gizi yang memadai. Makanan pendamping ASI (MPASI) diberikan sampai anak berusia dua tahun.

Cakupan ASI eksklusif di Kabupaten Bantul masih tergolong rendah. Idealnya bayi menerima ASI hingga usia dua tahun, tapi bila tidak memungkinkan maka minimal diberikan secara eksklusif pada enam bulan pertama. Persentase pemberian ASI pada tahun 2011 sebesar 42,3\%, meningkat dibandingkan tahun 2010 sebanyak $29,87 \%$ (2).

Berdasarkan profil Dinas Kesehatan Bantul tahun 2012 (2), cakupan ASI eksklusif di Puskesmas Sedayu I adalah $68 \%$, sedangkan cakupan ASI eksklusif Puskesmas Sedayu II adalah 44,56\%. Menurut keterangan kader posyandu setempat, pemberian ASI eksklusif di wilayah tersebut masih belum bisa optimal. Hal ini dapat dicontohkan di Desa Srontakan yang diketahui dari 13 wanita yang bekerja, 7 wanita menitipkan bayinya pada tetangga, 8 orang lainnya diasuh oleh keluarga sendiri. Lama kontak ibu dengan bayi hanya didapatkan saat cuti melahirkan dan setelah pulang kerja \pm 8 jam, sehingga frekuensi pemberian ASI menjadi berkurang (3). Berdasarkan latar belakang di atas sangat penting diteliti hubungan antara pola asuh dengan keberhasilan ASI eksklusif.

\section{BAHAN DAN METODE}

Penelitian ini merupakan penelitian analitik (induktif) dengan pendekatan kuantitatif yang didukung dengan data kualitatif. Penelitian ini menggunakan rancangan penelitian cross sectional, yaitu suatu penelitian yang mempelajari dinamika korelasi antara faktor-faktor risiko dengan efek, dengan cara pendekatan, observasi atau pengumpulan data sekaligus pada suatu saat (point time approach). Artinya, tiap subjek penelitian hanya diobservasi sekali saja dan pengukuran dilakukan terhadap status karakter atau variabel subjek pada saat pemeriksaan (4).

Populasi dalam penelitian ini adalah semua ibu yang memiliki baduta usia 6-24 bulan di Kecamatan Sedayu sejumlah 1.120 baduta. Dengan kriteria inklusi ibu yaitu bersedia menjadi responden dan kriteria eksklusi ibu atau bayi menderita penyakit berat serta ibu dan bayi tidak tinggal bersama. Sampel dalam penelitian ini diambil dengan menggunakan metode PPS yaitu metode sampling yang proporsional dengan ukuran populasi dari klaster.Hasil penghitungan mendapatkan 292 responden ibu menyusui yang berada di Kecamatan Sedayu, Bantul, Yogyakarta dari 30 posyandu terpilih.

Instrumen yang digunakan dalam pengumpulan data penelitian ini adalah kuesioner dan wawancara terarah atau focus group discussion (FGD). Kuesioner telah diuji validitas dan reliabilitas di Kecamatan Gamping. Analisis yang digunakan adalah analisis univariat dan bivariat dengan uji statistik chi-square menggunakan software SPSS 16.

\section{HASIL}

\section{Pengasuh utama anak}

Berdasarkan Tabel 1 didapatkan sebanyak $251(86 \%)$ baduta di Kecamatan Sedayu diasuh oleh ibu kandung dan sebagian lagi sebanyak 41 
(14\%) baduta diasuh oleh bukan ibu kandung seperti nenek, bibi, dan sebagainya.

Tabel 1. Distribusi frekuensi pengasuh utama anak

\begin{tabular}{lcc}
\hline \multicolumn{1}{c}{ Pengasuh } & Frekuensi & Persentase (\%) \\
\hline Ibu kandung & 251 & 86,0 \\
Bukan ibu kandung & 41 & 14,0 \\
Total & 292 & 100,0 \\
\hline
\end{tabular}

\section{Lama kontak}

Tabel 2 menggambarkan distribusi frekuensi lama kontak ibu menyusui hasil pengambilan data responden didapatkan sebagian besar ibu baduta di Kecamatan Sedayu memiliki waktu >6 jam dalam sehari untuk mengasuh anak yaitu 268 responden $(91,8 \%)$ dan 19 responden $(6,5 \%)$ memiliki waktu untuk mengasuh anaknya 3-6 jam/hari, sebagian lagi $5(1,7 \%)$ memiliki waktu 1-3 jam/hari.

Tabel 2. Distribusi frekuensi lama kontak ibu dan baduta

\begin{tabular}{lcc}
\hline \multicolumn{1}{c}{ Lama kontak } & Frekuensi & Persentase (\%) \\
\hline 1-3 jam & 5 & 1,7 \\
3-6 jam & 19 & 6,5 \\
$>6$ jam & 268 & 91,8 \\
Jumlah & 292 & 100 \\
\hline
\end{tabular}

\section{Pemberian ASI eksklusif}

Sebagian besar $(53,8 \%)$ ibu di Kecamatan Sedayu tidak memberikan ASI eksklusif (Tabel 3).

Tabel 3. Distribusi frekuensi pemberian ASI secara eksklusif di Kecamatan Sedayu tahun 2013

\begin{tabular}{lcc}
\hline \multicolumn{1}{c}{ Pemberian ASI } & Frekuensi & Persentase (\%) \\
\hline ASI eksklusif & 135 & 46,2 \\
Tidak ASI eksklusif & 157 & 53,8 \\
Jumlah & 292 & 100 \\
\hline
\end{tabular}

\section{Hubungan pengasuh dengan pemberian ASI eksklusif}

Tabulasi silang dan hasil uji statistik hubungan pengasuh dengan pemberian ASI eksklusif di Kecamatan Sedayu Bantul disajikan pada Tabel 4. Tabel 4 menunjukkan bahwa sebagian besar ibu yang menjadi pengasuh utama anak juga memberikan ASI eksklusif yaitu sebesar 123 responden $(48,8 \%)$. Sebagian lagi pengasuh bukan ibu kandung tidak memberikan ASI eksklusif sebesar 28 responden (70\%). Hasil perhitungan statistik menggunakan uji chi-square diperoleh $\mathrm{p}$ sebesar 0,019, sehingga dapat disimpulkan ada hubungan yang signifikan antara pengasuh utama anak dengan pemberian ASI eksklusif di Kecamatan Sedayu Bantul.

Nilai koefisien kontingensi sebesar 2,322 menunjukkan bahwa kekuatan hubungan antara pengasuh dengan pemberian ASI eksklusif adalah kuat karena berada pada kisaran 1,134-4,756. Nilai OR sebesar 4,27 menunjukkan bahwa anak yang diasuh oleh ibu kandung 4,27 kali lebih mungkin berhasil dalam pemberian ASI eksklusif dibanding anak yang tidak diasuh oleh ibu kandung.

\section{Hubungan lama kontak dengan pemberian ASI eksklusif}

Tabulasi silang dan hasil uji statistik hubungan pengasuh dengan pemberian ASI eksklusif di Kecamatan Sedayu Bantul disajikan pada Tabel 5. Tabel 5 menunjukkan bahwa sebagian besar ibu di Kecamatan Sedayu memiliki waktu untuk mengasuh anak setiap hari, sebesar 127 responden $(47,4 \%)$ menyatakan bahwa mereka mengasuh anak selama lebih dari 6 jam dalam sehari dan tetap

Tabel 4. Hubungan pengasuh dengan pemberian ASI eksklusif di Kecamatan Sedayu Bantul tahun 2013

\begin{tabular}{|c|c|c|c|c|c|c|c|c|c|c|}
\hline \multirow{3}{*}{ Pengasuh } & \multicolumn{4}{|c|}{ Pemberian ASI eksklusif } & \multirow{2}{*}{\multicolumn{2}{|c|}{ Total }} & \multirow{3}{*}{$\chi^{2}$} & \multirow{3}{*}{$\mathbf{p}$} & \multirow{3}{*}{$\begin{array}{l}\text { Cont. } \\
\text { coeff }\end{array}$} & \multirow{3}{*}{ OR } \\
\hline & \multicolumn{2}{|c|}{ ASI eksklusif } & \multicolumn{2}{|c|}{ Tidak ASI eksklusif } & & & & & & \\
\hline & $f$ & $\%$ & $\mathbf{F}$ & $\%$ & $f$ & $\%$ & & & & \\
\hline Ibu kandung & 123 & 49,0 & 128 & 51,0 & 251 & 100 & & & & \\
\hline Bukan ibu kandung & 12 & 29,3 & 29 & 70,7 & 41 & 100 & 5,522 & 0,019 & 2,322 & 4,27 \\
\hline Total & 135 & 46,2 & 157 & 53,8 & 292 & 100 & & & & \\
\hline
\end{tabular}


Tabel 5. Hubungan antara pengasuh dengan pemberian ASI eksklusif di Kecamatan Sedayu Bantul

\begin{tabular}{|c|c|c|c|c|c|c|c|c|c|}
\hline \multirow{3}{*}{ Lama kontak } & \multicolumn{4}{|c|}{ Pemberian ASI eksklusif } & \multirow{2}{*}{\multicolumn{2}{|c|}{ Total }} & \multirow{3}{*}{$\chi^{2}$} & \multirow{3}{*}{$\mathbf{p}$} & \multirow{3}{*}{$\begin{array}{l}\text { Cont } \\
\text { coef }\end{array}$} \\
\hline & \multicolumn{2}{|c|}{ ASI eksklusif } & \multicolumn{2}{|c|}{ Tidak ASI eksklusif } & & & & & \\
\hline & $\mathbf{F}$ & $\%$ & $f$ & $\%$ & $\mathbf{F}$ & $\%$ & & & \\
\hline 1-3 jam & 2 & 49,0 & 4 & 51,0 & 6 & 100 & & & \\
\hline 4-6 jam & 6 & 31,6 & 13 & 68,4 & 19 & 100 & 5,522 & 0,394 & 2,322 \\
\hline$>6$ jam & 127 & 47,4 & 141 & 52,6 & 268 & 100 & & & \\
\hline Total & 135 & 46,2 & 157 & 53,8 & 292 & 100 & & & \\
\hline
\end{tabular}

memberikan ASI eksklusif, sebanyak 6 responden $(31,6 \%)$ memiliki waktu untuk mengasuh anaknya 4-6 jam/hari dan memberikan ASI eksklusif, sebagian lagi 2 responden $(40,0 \%)$ memiliki waktu 1-3 jam/hari dan memberikan ASI eksklusif. Hasil perhitungan statistik menggunakan uji chi-square seperti disajikan pada Tabel 5, diperoleh nilai $p$ sebesar 0,394 sehingga dapat disimpulkan tidak ada hubungan yang signifikan antara pengasuh utama anak dengan pemberian ASI eksklusif di Kecamatan Sedayu Bantul 2013.

\section{BAHASAN}

\section{Karakteristik responden}

Dalam penelitian, ini total responden adalah 292 orang yang berasal dari 4 desa yaitu Argomulyo, Argorejo, Argodadi, Argosari. Jumlah responden tidak sesuai dengan perhitungan sampel awal yaitu sebesar 346 baduta karena ada ibu baduta yang menolak untuk diteliti serta ibu dan atau baduta yang mengalami penyakit berat.

Karakteristik responden berdasarkan umur menunjukkan bahwa sebagian besar responden berumur 30-34 tahun yaitu sebesar 81 orang $(27,7 \%)$. Umur tersebut merupakan rentang usia yang aman untuk bereproduksi dan pada umumnya ibu pada usia tersebut memiliki kemampuan lakatasi yang lebih baik daripada yang berumur 35 tahun. Dengan demikian ibu, yang berusia 20-35 tahun memiliki peluang yang lebih besar untuk memberikan ASI eksklusif kepada bayinya (5).

Hasil penelitian pada responden berdasarkan karakteristik pekerjaan menunjukkan sebagian besar ibu responden adalah ibu rumah tangga yaitu sebanyak 216 orang $(74,0 \%)$. Pekerjaan merupakan alasan yang sering digunakan oleh ibu untuk berhenti menyusui bayinya.Di daerah, ibu banyak turut bekerja mencari nafkah, sehingga tidak dapat menyusui bayinya secara teratur. Sebenarnya walaupun ibu bekerja, ibu masih bisa untuk dapat memberikan ASI kepada bayinya (5).

Hasil penelitian responden berdasarkan karakteristik pendidikan sebagian besar responden adalah SMA sebanyak 151 orang (34,8\%). Ibu menyusui dengan pendidikan yang tinggi akan menyadari pentingnya pemberian ASI secara eksklusif bagi tumbuh kembang bayi. Tingkat pendidikan dapat mempengaruhi faktor yang menentukan kemampuan ibu menyusui dalam mengonsumsi atau menyiapkan makanan untuk dirinya. Tinggi rendahnya tingkat pengetahuan ibu tersebut selanjutnya akan mempengaruhi status gizi ibu selama menyusui, status gizi ibu selanjutnya akan mempengaruhi produksi ASI (6).

Pada karakteristik baduta didapatkan baduta didominasi oleh anak pertama dan kedua, sebesar 138 baduta $(47,3 \%)$ dan selebihnya adalah anak kedua sebesar 107 baduta (36,6\%). Selebihnya sebesar 47 baduta $(16,1 \%)$ merupakan anak keempat, kelima, dan ketujuh. Jumlah anak yang sedikit memungkinkan ibu untuk merawat dan mengurus anaknya dengan lebih baik.Walaupun tidak secara otomatis mempengaruhi kualitas pengasuhan, tetapi dapat diasumsikan bahwa semakin banyak anak, maka perhatian orang tua pada masing-masing anak semakin kecil. Seperti dalam cuplikan FGD berikut ini:

"Biasanya bangun tidur yang kecil saya kasih ASI, kalo udah saya titipin sebentar sama bapaknya, aku masak lalu nyiapin baju sekolah anak-anak terus nganter sekolah anak-anak. "(Ny.M). 
Dari hasil FGD tersebut, ibu membagi waktunya untuk mengurus anak yang lebih besar sehingga anak yang lebih kecil dititipkan kepada semuanya.

\section{Pola asuh anak}

Pola asuh anak dalam penelitian ini setidaknya meliputi, siapa pengasuh anak dan ketersediaan waktu dalam mengasuh anak seperti penjelasan berikut ini.

\section{Pengasuh anak}

Menurut teori dari Lawrance Green dalam Notoatmodjo (7) menyatakan bahwa pekerjaan merupakan salah satu faktor pendukung dalam perilaku, salah satunya perilaku pemberian ASI eksklusif. Berdasar Tabel 4 diperoleh informasi bahwa sebagian besar responden merupakan ibu rumah tangga/tidak bekerja yaitu $216(74,0 \%)$ orang dibandingkan dengan yang bekerja sebanyak 76 $(26,0 \%)$ orang. Hasil penelitian menunjukkan bahwa sebagian besar ibu yang menjadi pengasuh utama bagi anak yaitu sebanyak 251 responden (86\%) dan sebagian lagi sebanyak 41 (14\%) pengasuh utama anak bukan ibu kandung seperti nenek, bibi, dan sebagainya.

\section{Lama kontak busui}

Tabel 4 menggambarkan sebagian besar ibu baduta di Kecamatan Sedayu memiliki waktu $>6$ jam dalam sehari untuk mengasuh anak yaitu 268 responden $(91,8 \%)$ dan 19 responden $(6,5 \%)$ memiliki waktu untuk mengasuh anaknya 3-6 jam/ hari. Sebagian lagi 5 responden $(1,7 \%)$ memiliki waktu 1-3 jam/hari. Walaupun sebagian besar ibu mempunyai waktu bersama anaknya di rumah, pada umumnya ibu baduta tetap mengerjakan pekerjaan rumah tangga mulai dari mencuci, menyapu, memasak, dan sebagainya. Hal ini serupa dengan penelitian Alma Ata Center for Healty and Food (ACHEAF) dan United Nation World Food (UNWFP) di NTT tahun 2013(8).

\section{Pemberian ASI eksklusif}

Sebagian besar responden tidak memberikan ASI eksklusif kepada bayinya yaitu sebanyak 157 responden (53,8 \%). Pemberian ASI eksklusif sangat penting dan terbukti memiliki hubungan dengan perkembangan bayi 7-12 bulan di Kecamatan Gading Cempaka Kota Bengkulu (9). Riwayat pola asuh yang kurang (dinilai dari pola pemberian makan dalam hal pemberian ASI dan MP-ASI) di Kecamatan Biboki Utara, Timor Tengah, Nusa Tenggara Timur berisiko terhadap kejadian stunting 14,5 kali lebih besar dibanding yang mendapat pola asuh baik (10).

\section{Hubungan pengasuh dengan pemberian ASI eksklusif}

Hasil analisis tabulasi silang (cross tab) diketahui bahwa ibu yang menjadi pengasuh utama anak sebagian besar memberikan ASI eksklusif yaitu sebanyak 123 orang (48,8\%), sedangkan jika pengasuh utama orang lain tidak memberikan ASI eksklusif sebanyak 28 orang (70\%). Hasil uji statistik menggunakan uji chi-square menunjukkan adanya hubungan yang signifikan antara pengasuh utama anak dengan pemberian ASI eksklusif $(p=0,019)$. Hasil analisis menunjukkan pengasuh ibu kandung dan memberikan ASI eksklusif sebesar $40 \%$ dan pengasuh yang bukan ibu kandung memberikan ASI eksklusif sebesar $29,3 \%$. Hal ini berarti ibu yang menjadi pengasuh utama memiliki persentase $20 \%$ lebih tinggi dalam memberikan ASI eksklusif dibandingkan pengasuh yang bukan ibu kandung.

Hasil penelitian ini didukung oleh penelitian sebelumnya yang dilakukan oleh Hamam Hadi, dkk yang menunjukkan adanya hubungan yang bermakna antara pengasuh dengan pemberian ASI eksklusif (8). Hal tersebut dimungkinkan karena ibu yang tidak mengasuh anaknya secara langsung, contohnya saja pada ibu pekerja yang menitipkan anak mereka.

Hasil FGD mendukung pernyataan ibu bekerja yang menitipkan anaknya dan ibu tidak bekerja yang mengasuh sendiri anaknya.

"Kalo kurang dari jam 08.00 biasanya bapaknya, lebih dari jam 08.00 mbahnya. Kalo mbahnya ke sawah sama mbah buyut... he'eh ya ...yakin tidak yakin, cuma adanya mbah buyut ". (Ny.D, Ibu bekerja).

"Ya saya sendiri mbak..tiap hari..haha". (Ny.Y, Ibu tidak bekerja) 
Hal tersebut juga didukung oleh informasi yang didapat mengenai pemberian ASI pada ibu tidak bekerja atau MPASI dini pada ibu yang bekerja.

"Umur seminggu itu udah saya coba susu formula soalnya mau ditinggal kerja. Kalo ngasih ma'emnya itu udah umur 1 bulan lebih itu dikasih pisang sama sun yang encer. " (Ny.D, Ibu bekerja)

"Saya eksklusif terus... ASI eksklusif terus selama 6 bulan tidak pernah dikasih madu atau air putih."(Ny.Y, Ibu tidak bekerja).

Berdasarkan hasil FGD di atas dapat disimpulkan jika pengasuhan oleh ibu kandung mempengaruhi ibu dalam memberikan ASI secara terus menerus.Ibu yang pengasuhnya adalah ibu kandung sendiri berpeluang lebih besar untuk memberikan ASI eksklusif.Sementara ibu yang bekerja memiliki peluang lebih kecil untuk memberikan ASI eksklusif. ASI eksklusif dapat dicapai apabila ibu bekerja memiliki intensi untuk memberikan ASI eksklusif sejak masa kehamilan, budaya dalam menyusui, manajemen laktasi, dan cara menangani hambatan menyusui (11).

\section{Hubungan lama kontak dengan pemberian ASI eksklusif}

Hasil analisis tabulasi silang (cross tab) diketahui lama kontak ibu 1-3 jam dengan tetap memberikan ASI eksklusif sebesar 2 responden (40\%), ibu dengan lama kontak 4-6 jam dan memberikan ASI eksklusif sebesar 6 responden $(31,6 \%)$ dan ibu yang memiliki kontak $>6$ jam dan memberikan ASI eksklusif sebesar 127 responden $(47,4 \%)$.

Hasil uji statistik menggunakan uji chi-square tidak menunjukkan adanya hubungan yang signifikan antara lama kontak ibu menyusui dengan pemberian ASI eksklusif.Menariknya, semakin lama waktu yang dimiliki oleh pengasuh untuk mengasuh anaknya per hari tidak diikuti dengan meningkatnya peluang anak untuk diberikan ASI eksklusif.Dibandingkan anak yang mempunyai kontak dengan pengasuhnya $\geq 6$ jam/hari tidak mempunyai peluang lebih besar untuk menerima ASI eksklusif. Hal ini mungkin terjadi karena kualitas kontak dengan anak itu lebih penting dan lebih menentukan dibandingkan lamanya kontak. Seperti pada hasil FGD yang meminta ibu untuk menjelaskan jenis aktivitas yang dilakukan mulai dari bangun tidur sampai dengan tidur kembali:

"Ya bangun tidur terus masak pokokmen pekerjaan rumah ya nyuci, ya apa gitu kalo udah selesai, ngasih makan, mandiin, nganterin yang gede sekolah..ya nanti kalo yang kecil udah tidur ya kerja lagi njahit, kalo anaknya gak rewel ya kerja kalo rewel ya diutamain anaknya. Malam anaknya udah bobok kerja lagi njahit " (Ny.N).

Hasil FGD mengenai keberhasilan ibu dalam memberikan ASI eksklusif:

"Mulai 3 bulan, udah tak kasih ma'em he..em.. buah pisang itu sama air putih..he em. supaya belajar ma'em "(Ny.N).

Dari hasil FGD tersebut dapat disimpulkan bahwa lama kontak ibu dengan anak cukup lama. Ibu masih mengerjakan pekerjaan rumah tangga dengan beban cukup banyak dan ibu juga di selasela waktu masih melakukan pekerjaan tambahan sehingga anak diberikan makanan pendamping ASI terlalu dini.

\section{KESIMPULAN DAN SARAN}

Proporsi ASI eksklusif di Kecamatan Sedayu sebesar $46,2 \%$. Sebagian besar ibu kandung di Kecamatan Sedayu yang menjadi pengasuh utama anak sebesar $86 \%$ dan sebagian lagi pengasuh utama anak sebesar $86 \%$ dan sebagian lagi pengasuh utama anak bukan ibu kandung seperti bibi, nenek dan sebagainya sebesar $14 \%$. Sebagian besar ibu di Kecamatan Sedayu Bantul memiliki waktu untuk mengasuh anak. Ibu baduta sebesar 268 responden $(91,8 \%)$ menyatakan bahwa mereka mengasuh anak selama lebih dari 6 jam dalam sehari, sebagian responden 19 (6,5\%) memiliki waktu untuk mengasuh anaknya 1-3 jam/ hari dan sebagian lagi 5 responden $(1,7 \%)$ memiliki waktu 1-3 jam/hari. Ada hubungan yang signifikan $(p=0,019)$ antara pengasuh dengan pemberian ASI eksklusif di Kecamatan Sedayu Bantul. Tidak 
ada hubungan yang signifikan $(p=0,394)$ antara lama kontak dengan pemberian ASI eksklusif di Kecamatan Sedayu Bantul.

Untuk Dinas Kesehatan dan Puskesmas Sedayu maupun profesi kebidanan disarankan untuk mensosialisasikan dan memotivasi ibu bekerja agar meskipun bekerja tetap menjadi pengasuh utama anaknya dan meningkatkan kualitas waktu pertemuan ibu dengan bayi sehingga tetap berhasil memberikan ASI eksklusif.

\section{RUJUKAN}

1. BKKN, Badan Pusat Statistik, Kementerian Kesehatan RI, Measure DHS. Survei demografi kesehatan Indonesia 2012. Jakarta: BKKN, Badan Pusat Statistik, Kementerian Kesehatan RI, Measure DHS; 2013.

2. Dinas Kesehatan Kabupaten Bantul. Profil Kesehatan Kabupaten Bantul. Bantul: Dinas Kesehatan Kabupaten Bantul; 2012.

3. Puskesmas Sedayu I. Profil Kesehatan Puskesmas Sedayu I 2012. Bantul: Puskesmas Sedayu I; 2012.

4. Notoatmodjo S. Metodologi penelitian kesehatan. Jakarta: Rineka Cipta; 2012.

5. Roesli U. Inisiasi menyusu dini plus ASI eksklusif. Jakarta: Pustaka Bunda; 2008.
6. Kementerian Kesehatan Republik Indonesia. Pedoman pekan ASI sedunia (PAS) 2012. Jakarta: Kementerian Kesehatan Republik Indonesia; 2012.

7. Notoatmodjo S. Pendidikan dan perilaku kesehatan. Jakarta: Rineka Cipta; 2003.

8. Alma Ata Centre for Healty and Food (ACHEAF), United Nation World Food Program ( UN-WPF). Analisis tentang perilaku dan praktek konsumsi makanan/diet pada anak dibawah 5 tahun, anak sekolah, ibu hamil dan menyusui di Kabupaten Timor Tengah Selatan, Provinsi Nusa Tenggara Timur, Indonesia. Yogyakarta: Alma Ata Centre for Healty and Food ( ACHEAF) United Nation World Food Program ( UN-WPF); 2013.

9. Kamsiah, Nurdiati D, Huriyati E. ASI eksklusif berhubungan dengan perkembangan bayi di Kecamatan Gading Cempaka Kota Bengkulu. J Gizi dan Diet Indones. 2013;1(1):39-43.

10. Nabuasa, CD, Juffrie, M, Huriyati E. Riwayat pola asuh, pola makan, asupan zat gizi berhubungan dengan terhadap kejadian stunting pada anak usia 24-59 bulan di Kecamatan Biboki Utara Kabupaten Timor Tengah Utara Provinsi Nusa Tenggara Timur. J Gizi dan Diet Indones. 2013;1(3):31-43.

11. Agustina I. Keberhasilan ibu bekerja memberikan ASI eksklusif. J Gizi dan Diet Indones. 2015;3(2):69-76. 